\title{
Hydrological heterogeneity in Mediterranean reclaimed slopes: runoff and sediment yield at the patch and slope scales along a gradient of overland flow
}

\author{
L. Merino-Martín ${ }^{1}$, M. Moreno-de las Heras ${ }^{1,2}$, S. Pérez-Domingo ${ }^{1}$, T. Espigares ${ }^{1}$, and J. M. Nicolau ${ }^{3}$ \\ ${ }^{1}$ Departamento de Ecología, Universidad de Alcalá, Alcalá de Henares, 28871 Madrid, España \\ ${ }^{2}$ Faculty of Engineering and Built Environment, University of Newcastle, Callaghan, NSW 2308, Australia \\ ${ }^{3}$ Departamento de Agricultura y Economía agraria, Escuela Politécnica Superior, Universidad de Zaragoza, Huesca, España
}

Correspondence to: L. Merino-Martín (luis.merino@uah.es)

Received: 21 October 2011 - Published in Hydrol. Earth Syst. Sci. Discuss.: 14 November 2011

Revised: 19 March 2012 - Accepted: 9 April 2012 - Published: 8 May 2012

\begin{abstract}
Hydrological heterogeneity is recognized as a fundamental ecosystem attribute in drylands controlling the flux of water and energy through landscapes. Therefore, mosaics of runoff and sediment source patches and sinks are frequently identified in these dry environments. There is a remarkable scarcity of studies about hydrological spatial heterogeneity in restored slopes, where ecological succession and overland flow are interacting. We conducted field research to study the hydrological role of patches and slopes along an "overland flow gradient" (gradient of overland flow routing through the slopes caused by different amounts of run-on coming from upslope) in three reclaimed mining slopes of Mediterranean-continental climate. We found that runoff generation and routing in non-rilled slopes showed a pattern of source and sink areas of runoff. Such hydrological microenvironments were associated with seven vegetation patches (characterized by plant community types and cover). Two types of sink patches were identified: shrub Genista scorpius patches could be considered as "deep sinks", while patches where the graminoids Brachypodium retusum and Lolium perenne dominate were classified as "surface sinks" or "runoff splays". A variety of source patches were also identified spanning from "extreme sources" (Medicago sativa patches; equivalent to bare soil) to "poor sources" (areas scattered by dwarf-shrubs of Thymus vulgaris or herbaceous tussocks of Dactylis glomerata). Finally, we identified the volume of overland flow routing
\end{abstract}

along the slope as a major controlling factor of "hydrological diversity" (heterogeneity of hydrological behaviours quantified as Shannon diversity index): when overland flow increases at the slope scale hydrological diversity diminishes.

\section{Introduction}

Spatial heterogeneity is a fundamental ecosystem attribute in drylands that controls the flux of resources (e.g. water and nutrients) and energy through landscapes (Noy-Meir, 1973; Schlesinger et al., 1990). Consequently, water-limited landscapes are generally arranged in a mosaic of patches with diverse hydrological role, where surface fluxes of water runoff and sediments interact with vegetation dynamics (Lavee et al., 1998; Puigdefábregas, 2005). The TriggerTransfer-Reserve-Pulse (hereafter TTRP) conceptual model developed by Ludwig et al. $(1997,2005)$ represents a useful framework for the understanding of these systems. This approach suggests that these ecosystems are structured as a mosaic of densely vegetated patches, with resource-sink hydrological role, interspaced within a bare soil or scarcely vegetated component, with resource-source hydrological role. The transfer of water and sediments from the bare source areas to vegetated patches (i.e. sinks) maximizes the use of resources, producing pulses of vegetation growth, which increase the ability of vegetation patches to capture surface

Published by Copernicus Publications on behalf of the European Geosciences Union. 
resource fluxes and hence, enhance water and soil conservation at the landscape level.

Several studies have highlighted the operation of coupled eco-hydrological processes described by the TTRP conceptual framework in many semiarid and arid ecosystems throughout the world, including Niger (Seghieri et al., 1997; Bromley et al., 1997), Jordan (White, 1969), Australia (Dunkerley and Brown, 1995), USA (Reid et al., 1999; Turnbull et al., 2010; Wainwright et al., 2002) and Spain (CalvoCases et al., 2003). Further work refined the principles of this approach, explaining that the sink-source hydrological role of vegetation patches does not only depend on vegetation density, but also on the specific traits of the dominant plant species growing in them (Bochet et al., 2006; GarciaEstringana et al., 2010; Vasquez-Mendez et al., 2010).

The effects of disturbance on these resource-conserving natural ecosystems are well known: rises in runoff generation and soil erosion, frequently associated with the development of rill or gully networks (Davenport et al., 1998; Ludwig and Tongway, 2000; Wilcox et al., 2003). Under these conditions, vegetation patches are not able to capture water and sediments efficiently, causing a significant loss of resources at the landscape scale. These losses reduce vegetation growth and, in consequence, cause the activation of a long-term selfreinforced degradation process. Similar mechanisms operate in degraded human-made slopes under Mediterraneandry climate (Nicolau, 2002). The dynamics of these reclaimed ecosystems are modulated by the amount of overland flow routed through the slopes, which in some cases is very high, favoured by structurally poor soils, rough topographical designs, and occasionally, the presence of runoff contributing areas (e.g. steep berms, tracks, etc.) located at the top of slopes (Moreno-de las Heras et al., 2008; Hancock and Willgoose, 2004). When the amount of overland flow is high, intense soil erosion processes develop; rill erosion being the most significant phenomenon. Rill networks drain runoff away from slopes efficiently, reducing water infiltration, thus increasing the water deficit (Bracken and Kirkby, 2005; Moreno-de las Heras et al., 2010). As a result, vegetation dynamics are affected, constraining seed germination, plant establishment and development, and seed production (Espigares et al., 2011). These mechanisms drive the reclaimed ecosystem towards a highly degraded state, in which a very costly intervention is required to facilitate vegetation recovery (Nicolau, 2003; Merino-Martín et al., 2011).

To date, the study of the interactions between the dynamics of overland flow and vegetation has focused on degradation processes affecting both natural and reclaimed semiarid environments (Turnbull et al., 2008, 2010). Notably lacking are studies that focus on the opposite ecosystem recovery phenomenon. Reclaimed mining environments offer excellent opportunities for the elucidation of the structural and functional dynamics of ecological systems, where soils and vegetation are in general very simple, so that plant communities and hydrological processes represent early stages of ecosystem organization (Bradshaw, 1983). In this study, we analyze hydrological processes (i.e. runoff generation and routing and sediment yield) acting at the patch and slope scales in Mediterranean-dry reclaimed mining slopes with sparse vegetation and with absent or poorly developed rill networks (i.e. spatially discontinuous). Previous work carried out in the same study area (Moreno-de las Heras et al., 2009,2010 ) indicated that under these conditions overland flow is not routed by rill networks, running mostly as sheet flow over the surface, so the vegetation is able to establish successfully on slopes, promoting a wide diversity of vegetation patches dominated by a variety of plant species with different cover. We specifically aimed to: (a) evaluate the heterogeneity of hydrological roles developed at the patch and slope scales in water-limited reclaimed slopes under the perspective of the ecosystem recovery processes; and (b) analyze the interaction of this hydrological heterogeneity with the amount of overland flow routed along the slopes.

We state as a fundamental assumption that the different vegetation patches developed in these Mediterranean-dry reclaimed slopes have diverse hydrological roles that can be functionally categorized as sources or sinks of resources, in accordance with the TTRP conceptual framework (Ludwig et al., 1997, 2005). Furthermore, we hypothesize that the hydrological heterogeneity of these reclaimed ecosystems is modulated by the amount of overland flow running at the slope scale. This overland flow will increase the complexity of surface hydrological role as it decreases, as that would indicate efficient runoff redistribution across the slope between different patches fulfilling different hydrological roles. In addition, we hypothesize that we can find two mosaic-generating processes along the overland flow gradient: mosaics driven by differential erosion (e.g. Wainwright et al., 2002), where plant cover plays a passive role, and mosaics driven by vegetation (e.g. Puigdefábregas, 2005), where vegetated patches become hot-spots of soil and vegetation change.

\section{Methods}

\subsection{Study area}

The study site is located within the Utrillas coalfield $(\sim 1100 \mathrm{~m}$ above sea level) in the Iberian Mountain Chain (Teruel, Spain; Fig. 1). This work was carried out in three reclaimed coal mining slopes located at El Moral spoil bank $\left(40^{\circ} 47^{\prime} 50^{\prime \prime} \mathrm{N}, 0^{\circ} 50^{\prime} 26^{\prime \prime} \mathrm{W}\right)$. Those slopes were selected to span a gradient of overland flow (i.e. three scenarios subjected to the routing of different amounts of overland flow). The climate is Mediterranean-Continental with mean annual temperature of $14^{\circ} \mathrm{C}$ (ranging from a minimum mean daily temperature of $6.7^{\circ} \mathrm{C}$ in December and a maximum mean daily temperature $23.1^{\circ} \mathrm{C}$ in July), with an air frost period between October and April. The local moisture regime can 


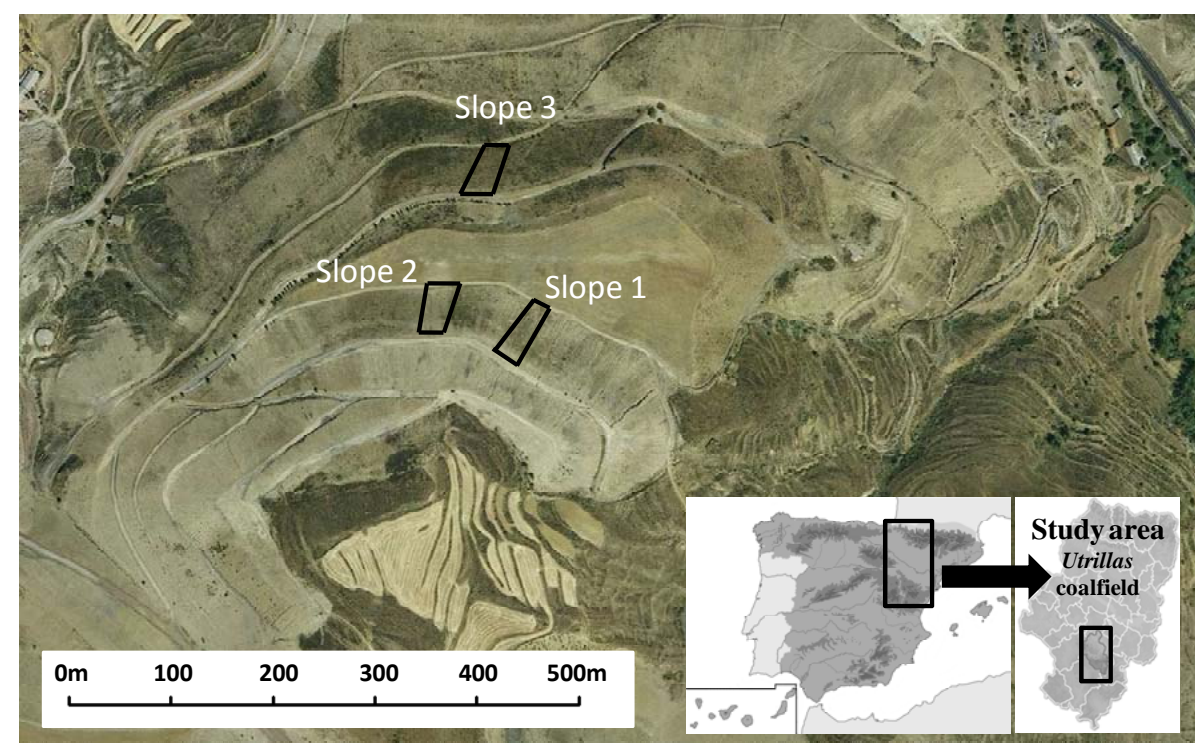

Fig. 1. Location map of area and slopes under study.

be classified as dry Mediterranean (Papadakis, 1966) with mean annual precipitation of $466 \mathrm{~mm}$ (mainly concentrated in spring and autumn) and potential evapotranspiration of $759 \mathrm{~mm}$, yielding a hydrological deficit of $292 \mathrm{~mm}$ running from June to October. The mean number of annual rainfall events in the area is $\sim 50$, with some convective rainstorms occurring especially in summer, characterized by high rainfall intensities of up to $100 \mathrm{~mm}$ in $24 \mathrm{~h}$ (Peña et al., 2002).

The slopes were built between 1987 and 1988 by the Minas y Ferrocarril de Utrillas S.A. mining company. They were built with an inclination between $18^{\circ}$ and $20^{\circ}$ and were covered with a layer of $80-100 \mathrm{~cm}$ clay-loam overlying substratum from the Escucha Cretaceous formation (Albian age) free of major physicochemical constraints (see Table 1 for a detailed description of slopes and soils). Revegetation of slopes was implemented after cross-slope ploughing by sowing a mixture of perennial grasses (Festuca rubra, Festuca arundinacea, Poa pratensis and Lolium perenne) and leguminous herbs (Medicago sativa and Onobrychis viciifolia). Although the slopes were restored using the same general procedures, they differed in their subsequent evolution (i.e. rilling, vegetation development), due to differences in their geomorphological design, chiefly in the upper part (Moreno-de las Heras et al., 2008, 2009). These geomorphological differences are due to the existence of a $40^{\circ}$ steep berm (barely covered; <3\%) integrated at the top of some slopes (Fig. 2a and b) which acts as a water-contributing area, generating important amounts of overland flow and promoting erosion processes. Although there are no significant differences in soil traits between slopes (Table 1), differences in the size of the up-slope water contributing area and its associated erosion processes (discontinuous rilling on slope 1 and sheet flow on slopes 2 and 3 ) have promoted large differences in vegetation development. This situation gave us the opportunity to select three reclaimed scenarios subjected to a variable amount of overland flow routed along the slopes since their construction (i.e. overland flow gradient).

\subsection{Hydrological measurements}

The hydrological year in the study site lasts from early autumn to the end of the next summer; however, due to the scarcity of rain events during the autumn of 2007, the sampling period was extended until December 2008. Therefore, runoff and sediment yield at slope and patch scales were monitored on the three experimental slopes from October 2007 to December 2008. This experimental layout at both scales is recommended in bibliography as a system of "nested plots" (Boix-Fayos et al., 2006; Cammeraat, 2002).

At the slope scale, naturally delimited catchments (unbounded plots) were selected (Fig. 2a-c). Therefore, the area of the slope-scale plots differed between the three slopes (see Table 1). At the foot of each slope catchment two plastic collectors were installed and a central cemented outlet fed into these collectors. Runoff was guided through a pipe from the outlet into two 200-1 storage tanks connected by a ten-slot runoff divider.

At the patch scale, a variable number of Gerlach plots were installed, encompassing the different vegetation patches present in slopes. Overall, we found seven different types of patches dominated by different plant species (see Table 2 for a detailed description of vegetation cover and soil structural properties of patches). Those patches were: (1) scattered clumps of legumes (M. sativa) and (2) grasses (Dactylis glomerata) in a matrix of bare soil. Scattered dwarf shrubs dominated by (3) Santolina chamaecyparissus and 


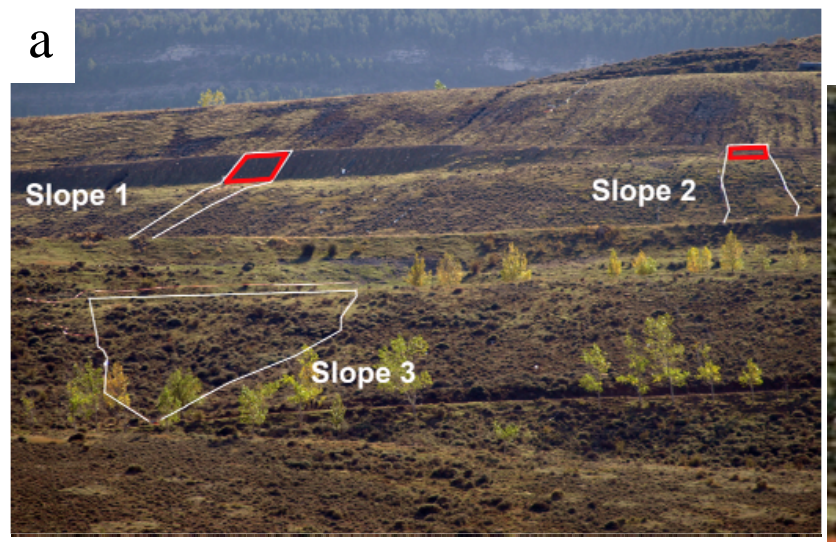

b Slope 1

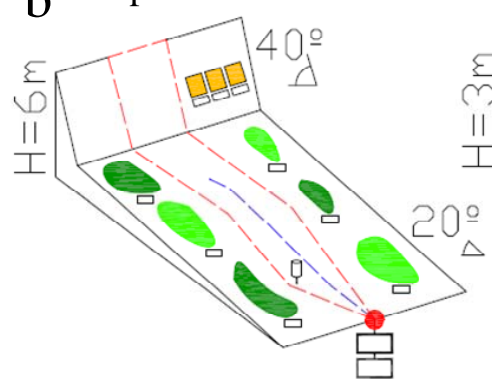

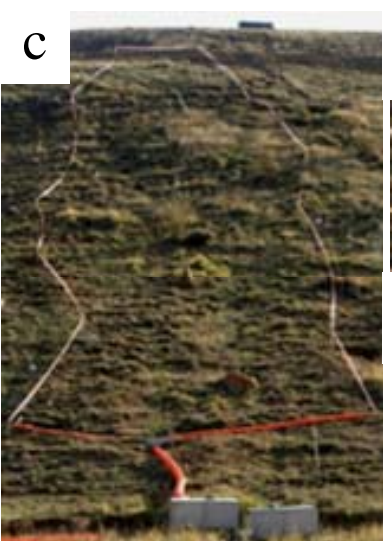

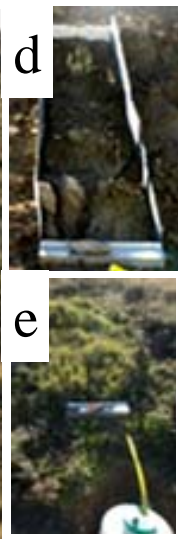

Slope 3
Slope 2

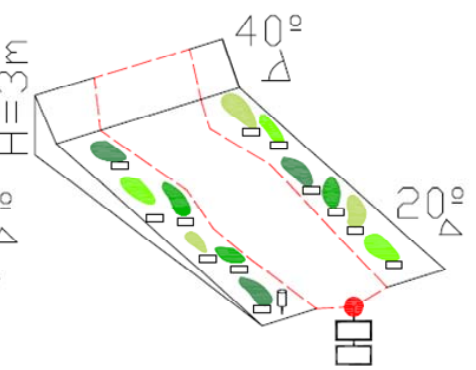

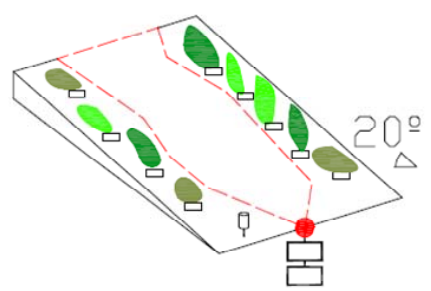

Fig. 2. (a) Location of the three experimental slopes at the El Moral spoil-bank (in red colour water contributing areas); (b) schematic representation of the experimental layout at slopes; (c) example of a slope plot on Slope 2; (d) example of Gerlach plot on Medicago patch; (e) example of Gerlach plot on Brachypodium patch.

by (4) Thymus vulgaris in a matrix of bare soil. Finally, we found patches densely covered by grasses dominated by (5) L. perenne and (6) Brachypodium retusum and others by (7) shrubs (Genista scorpius).

Three unbounded Gerlach plots $0.5 \mathrm{~m}$ wide (connected to 1001 runoff storage drums) per patch type were established in each slope (Fig. 2e) except for M. sativa patches, since the high runoff volumes produced by these patches compromised the operability of the experimental design. For M. sativa patches, bounded $3 \mathrm{~m}$ long Gerlach plots were used $(0.5 \mathrm{~m}$ wide; Fig. 2d). A 3 m length Gerlach plot was selected for these patches according to previous results obtained in the study site, which showed a low scale-dependency of hydrological responses in plots of this length (Moreno-de las Heras et al., 2010). Catchment areas of the unbounded Gerlach plots were visually delimitated on the basis of surface microtopography and vegetation barriers, and ranged from 1 to $16 \mathrm{~m}^{2}$.

Runoff collected from plots was measured after each runoff event (runoff-producing rainfalls occurring within a $24 \mathrm{~h}$ period were considered the same event). Runoff was determined by measuring water level in the container and calculating final volume using the relevant geometric equations. During the study period, no runoff event exceeded the storage capacity of tanks and drums, there was not either any significant losses from tanks attributable to evaporation. The stored runoff was stirred, and a representative 11 sample was taken by filling a 11 plastic bottle from the bottom up in order to obtain an integrated sample. Sediment concentrations were determined by oven-drying the collected runoff sample (at $105^{\circ} \mathrm{C}$ ) until a constant weight was achieved. Precipitation amount and characteristics were measured using an automatic recording rain gauge (GroWeather, Davis ${ }^{\circledR}$ ) located about $500 \mathrm{~m}$ from experimental slopes. Total precipitation was also recorded using three pluviometers, each located on one experimental slope. According to pluviometer data, spatial variations in precipitation during the study period were negligible.

\subsection{Topographic and microtopographic measurements}

A total station was used to carry out a topographical survey by tacheometry, defining the surface of the vegetation patches. Filling points and break lines were defined in order to determine slope topography. In each slope, the presence of micro-topographic structures and species vegetation cover was registered in $3550 \times 50 \mathrm{~cm}$ plots (seven plots regularly distributed in five transects along the slope). 
Table 1. Descriptive features for the three experimental slopes (mean $\pm \mathrm{SE}$ ).

\begin{tabular}{|c|c|c|c|c|c|c|c|}
\hline & $N^{*}$ & \multicolumn{2}{|l|}{ Slope 1} & \multicolumn{2}{|l|}{ Slope 2} & \multicolumn{2}{|l|}{ Slope 3} \\
\hline Date of reclamation & \multicolumn{3}{|c|}{1988} & \multicolumn{2}{|l|}{1988} & \multicolumn{2}{|l|}{1987} \\
\hline \multicolumn{8}{|c|}{ Topography } \\
\hline Slope area $\left(\mathrm{m}^{2}\right)$ & \multicolumn{3}{|c|}{497.5} & \multicolumn{2}{|l|}{510.6} & \multicolumn{2}{|l|}{1474.3} \\
\hline Slope gradient $\left({ }^{\circ}\right)$ & \multicolumn{3}{|c|}{20} & \multicolumn{2}{|l|}{20} & \multicolumn{2}{|l|}{20} \\
\hline Water-Contributing Area $\left(\mathrm{m}^{2}\right)$ & \multicolumn{3}{|c|}{50.4} & \multicolumn{2}{|l|}{22.7} & \multicolumn{2}{|l|}{0} \\
\hline Aspect & \multicolumn{3}{|c|}{ North } & North & & \multicolumn{2}{|l|}{ North } \\
\hline \multicolumn{8}{|c|}{ Soil traits ${ }^{1}$} \\
\hline Stoniness $(\%)$ & 9 & $39.2 \pm 4.5$ & $\mathrm{a}$ & $40.5 \pm 3.2$ & $\mathrm{a}$ & $41.9 \pm 3.4$ & a \\
\hline Sand $(\%)$ & 9 & $44.8 \pm 2.6$ & $\mathrm{a}$ & $45.6 \pm 2.7$ & $\mathrm{a}$ & $44.0 \pm 3.0$ & $\mathrm{a}$ \\
\hline Silt $(\%)$ & 9 & $28.7 \pm 0.3$ & $\mathrm{a}$ & $25.2 \pm 1.1$ & $\mathrm{a}$ & $29.8 \pm 1.2$ & a \\
\hline Clay $(\%)$ & 9 & $26.6 \pm 2.4$ & $\mathrm{a}$ & $29.3 \pm 1.6$ & $\mathrm{a}$ & $26.3 \pm 1.8$ & $\mathrm{a}$ \\
\hline Texture & 9 & Clay loam & & Clay loam & & Clay loam & \\
\hline $\mathrm{pH}-\mathrm{H}_{2} \mathrm{O} ; \mathrm{w} / \mathrm{v}^{* * *}: 1 / 2-$ & 9 & $8.4 \pm 0.3$ & $\mathrm{a}$ & $8.3 \pm 0.2$ & $\mathrm{a}$ & $8.01 \pm 0.2$ & a \\
\hline $\mathrm{EC}^{* *}-\mathrm{w} / \mathrm{v}^{* * *}: 1 / 2-\left(\mathrm{dS} \mathrm{m}^{-1}\right)$ & 9 & $0.3 \pm 0.1$ & $\mathrm{a}$ & $0.3 \pm 0.01$ & $\mathrm{a}$ & $0.7 \pm 0.4$ & a \\
\hline Organic matter $(\%)$ & 9 & $1.2 \pm 0.3$ & $\mathrm{a}$ & $1.6 \pm 0.34$ & $\mathrm{a}$ & $2.0 \pm 0.4$ & $\mathrm{a}$ \\
\hline $\mathrm{CaCO}_{3}(\%)$ & 9 & $7.3 \pm 0.4$ & $\mathrm{a}$ & $6.2 \pm 0.38$ & $\mathrm{a}$ & $6.8 \pm 0.3$ & $\mathrm{a}$ \\
\hline Bulk density ${ }^{2}\left(\mathrm{Mg} \mathrm{m}^{-3}\right)$ & 27 & $1.5 \pm 0.1$ & $\mathrm{a}$ & $1.5 \pm 0.03$ & $\mathrm{a}$ & $1.4 \pm 0.01$ & $\mathrm{a}$ \\
\hline \multicolumn{8}{|c|}{ Cover features ${ }^{3}$} \\
\hline Bare soil cover $(\%)$ & 105 & $44.6 \pm 3.1$ & $\mathrm{a}$ & $32.3 \pm 3.9$ & $\mathrm{~b}$ & $23.7 \pm 2.8$ & $\mathrm{~b}$ \\
\hline Stone cover $(\%)$ & 105 & $25.5 \pm 3.0$ & $\mathrm{a}$ & $22.7 \pm 1.6$ & $\mathrm{a}$ & $21.1 \pm 2.6$ & $\mathrm{a}$ \\
\hline Litter cover $(\%)$ & 105 & $5.4 \pm 1.8$ & $\mathrm{a}$ & $1.1 \pm 0.4$ & $\mathrm{~b}$ & $4.0 \pm 1.9$ & $\mathrm{ab}$ \\
\hline Vegetation cover $(\%)$ & 105 & $24.4 \pm 2.8$ & a & $43.9 \pm 4.1$ & $\mathrm{~b}$ & $51.2 \pm 4.2$ & $\mathrm{~b}$ \\
\hline \multicolumn{8}{|c|}{ Plant traits ${ }^{3}$} \\
\hline Species Richness & 105 & $3.83 \pm 0.28$ & $\mathrm{a}$ & $6.43 \pm 0.44$ & $\mathrm{~b}$ & $9.26 \pm 0.55$ & $\mathrm{c}$ \\
\hline Shannon's index & 105 & $0.80 \pm 0.08$ & $\mathrm{a}$ & $1.21 \pm 0.08$ & $\mathrm{~b}$ & $1.30 \pm 0.08$ & $\mathrm{~b}$ \\
\hline \multicolumn{8}{|c|}{ Erosion features } \\
\hline Sheet Erosion Index ${ }^{4}$ & 9 & $0.70 \pm 0.09$ & $\mathrm{a}$ & $0.59 \pm 0.05$ & $\mathrm{a}$ & $0.52 \pm 0.06$ & $\mathrm{a}$ \\
\hline Rill density ${ }^{5}\left(\mathrm{~m} \mathrm{~m}^{-2}\right)$ & 3 & 0.58 & & 0.00 & & 0.00 & \\
\hline Rill $^{6}$ erosion rate ${ }^{4}$ t ha $\left.^{-1} \mathrm{yr}^{-1}\right)$ & 3 & 8.41 & & 0.00 & & 0.00 & \\
\hline
\end{tabular}

Abbreviations: ${ }^{*} N$ : Number of samples; ${ }^{* *}$ EC: Electrical conductivity; ${ }^{* * *}$ w/v: relation weight (soil)/volume (water).

${ }^{1}$ Measured in three composite samples (each formed by three subsamples) from the first $10 \mathrm{~cm}$ in three transects regularly distributed along the slope. ${ }^{2}$ Measured in nine randomly distributed unaltered soil cores ( $3 \mathrm{~cm}$ height by $5 \mathrm{~cm}$ diameter). ${ }^{3}$ Cover, visually estimated in 35 regularly distributed $0.25 \mathrm{~m}^{2}$ plots per slope during spring $2006 .{ }^{4}$ Measured by the relationship: stone cover/stoniness; following Moreno-del Heras et al. (2008). ${ }^{5}$ Linear rill length (m) measured per surface area ( $\left.\mathrm{m}^{2}\right) .{ }^{6} \mathrm{Measured}$ from rill network dimensions following Morgan (1995).

All physico-chemical soil characteristics were analyzed following standardized methods proposed by the Spanish Ministry of Agriculture (MAPA, 1994). Values with the same letters (a-c) within rows do not differ significantly at $\alpha=0.05$. Tested using Kruskal-Wallis and Mann-Whitney post-hoc tests.

\subsection{Soil moisture measurements}

In order to test differences in soil water content between types of patches, TDR (Time Domain Reflectometry) sensors were horizontally installed at $25 \mathrm{~cm}$ into the soil. The TDR sensors were placed at $25 \mathrm{~cm}$ depth to study the interrelationships between patch cover and infiltration (mainly driven by macropores). Four replicates of each vegetation patch were selected for these measurements. A TDR cable tester (Tektronix ${ }^{\circledR}$ 1502C), was used to collect the data, following the methodology proposed by Cassel et al. (1994), with an accuracy of $94 \%$ in soil moisture determination. Soil water content data was collected within 5 days after each precipitation event.

\subsection{Data analyses}

Differences in runoff and sediment yield at the slope scale were analysed using Kruskal-Wallis and posthoc Mann-Whitney non-parametric tests. Differences in runoff, sediment yield and soil water content at the patch scale were analysed using non parametric tests for repeated measures (Friedman test and post-hoc 
Table 2. Characteristics of each patch present in the slopes under study.

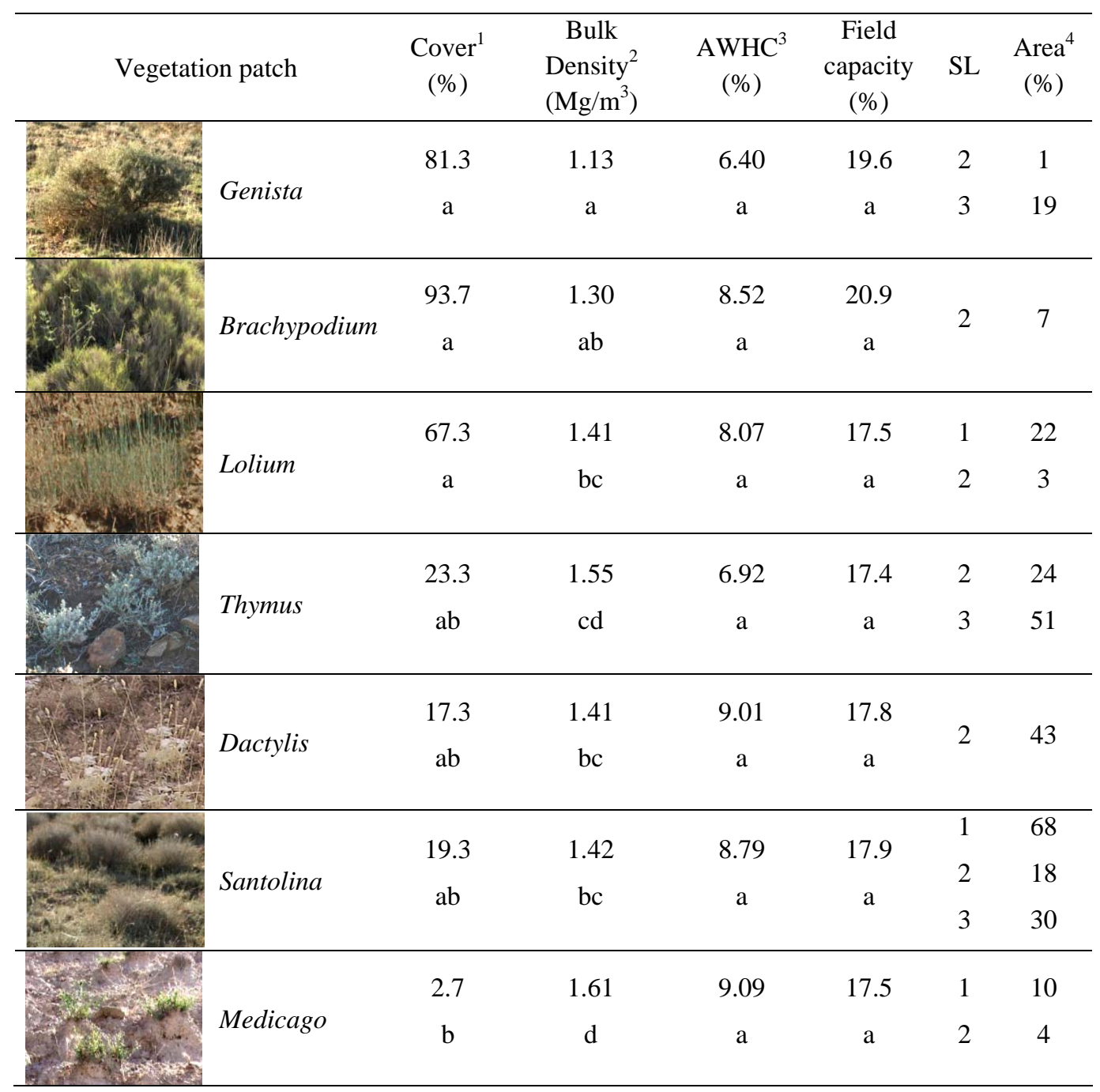

Abbreviations: AWHC = available Water Holding Capacity. SL= slope in which a patch is present. Values with the same letters (a-d) within rows do not differ significantly at $\alpha=0.05$. Analyzed with Kruskal-Wallis and Mann-Whitney U post-hoc tests.

${ }^{1}$ Cover visually estimated in six $0.25 \mathrm{~m}^{2}$ plots per vegetation patch in spring 2008 distributed in patches selected randomly. ${ }^{2}$ Measured in unaltered soil cores ( $3 \mathrm{~cm}$ height by $5 \mathrm{~cm}$ diameter) in fifteen samples in each vegetation patch distributed in patches selected randomly. ${ }^{3}$ Measured in a pressure-membrane apparatus following Richards (1941) as the difference between volumetric water content at field capacity ( $\Psi=-0.03 \mathrm{MPa}$ ) and wilting point $(\Psi=-1.5 \mathrm{MPa})$ in three samples (each formed by three subsamples) from the top $10 \mathrm{~cm}$ distributed in patches selected randomly. ${ }^{4}$ Area estimated from the total of the slope area for each slope (SL).

Wilcoxon-Nemenyi-McDonald-Thompson test; Hollander and Wolfe, 1999). In order to analyze the influence of rainfall characteristics on the hydrological role of the different patches, we used linear regressions to relate runoff and sediment yield with rainfall properties (depth and intensity). Runoff, soil moisture and sediment yield data were used to perform a cluster analysis (Tryon, 1939) to separate out groups of patches with homogeneous hydrological role. The linkage rule employed was Ward's method and City-block (Manhattan) as distances measures. We used Chi-Square test to analyze if there were significant relationships between vegetation patch hydrological behaviours and micro-topographic structures.

We estimated the "hydrological diversity" of each slope by computing the Shannon diversity index, for which we included the hydrological groups obtained from the cluster analysis as species. This diversity index is dependent of both the richness and abundance (vegetation patch) of each hydrological group and is a quantitative descriptor of the heterogeneity of hydrological behaviours.

Statistical analyses were performed using STATISTICA (Statsoft, 2001). Post-hoc Wilcoxon-NemenyiMcDonald-Thompson tests were performed with the 
Table 3. Rainfall characteristics, runoff and sediment yield of slopes.

\begin{tabular}{|c|c|c|c|c|c|c|c|c|c|c|}
\hline \multirow[t]{2}{*}{ Event } & \multirow[t]{2}{*}{ Date } & \multirow{2}{*}{$\begin{array}{r}\text { Storm } \\
\text { depth } \\
(\mathrm{mm})\end{array}$} & \multirow{2}{*}{$\begin{array}{l}I_{30}^{1} \\
\left(\mathrm{~mm} \mathrm{~h}^{-1}\right)\end{array}$} & \multirow{2}{*}{$\begin{array}{r}\text { Duration }^{2} \\
(\text { min })\end{array}$} & \multicolumn{3}{|c|}{$\mathrm{Rf}^{3}(\mathrm{~mm})$} & \multicolumn{3}{|c|}{$\mathrm{Sy}^{4}\left(\mathrm{~g} \mathrm{~m}^{-2}\right)$} \\
\hline & & & & & $\mathrm{SL}_{1}{ }^{5}$ & $\mathrm{SL} 2^{5}$ & $\mathrm{SL}^{5}$ & $\mathrm{SL}^{5}{ }^{\circ}$ & $\mathrm{SL} 2^{5}$ & $\mathrm{SL}^{5}{ }^{5}$ \\
\hline 3 & 9 May 2008 & 120.11 & 15 & 30 & 17.18 & 1.01 & 0.18 & 187.23 & 3.06 & 0.18 \\
\hline 5 & 17 May 2008 & 73.68 & 12 & 105 & 9.72 & 3.94 & 1.19 & 125.41 & 2.71 & 0.89 \\
\hline 8 & 9 Jun 2008 & 48.45 & 9 & 555 & 13.82 & 2.60 & 1.33 & 13.82 & 8.53 & 1.01 \\
\hline 17 & 2 Nov 2008 & 48.24 & 7 & 840 & 19.76 & 2.78 & 0.22 & 131.77 & 1.20 & 0.17 \\
\hline 9 & 29 Jun 2008 & 45.42 & 24.8 & 270 & 4.96 & 0.25 & 0.03 & 93.14 & 1.64 & 0.43 \\
\hline 6 & 23 May 2008 & 36.34 & 9.5 & 90 & 5.36 & 0.49 & 0.05 & 151.03 & 20.33 & 0.29 \\
\hline 10 & 17 Jul 2008 & 32.50 & 4.4 & 210 & 4.15 & 0.82 & 0.02 & 619.81 & 26.82 & 0.18 \\
\hline 16 & 28 Oct 2008 & 28.87 & 4.5 & 765 & 7.47 & 0.67 & 0.03 & 8.67 & 0.32 & 0.06 \\
\hline 1 & 9 Mar 2008 & 28.86 & 5.5 & 90 & 0.01 & 0.00 & 0.00 & 1.93 & 0.00 & 0.00 \\
\hline 7 & 31 May 2008 & 27.25 & 3.5 & 210 & 1.35 & 0.08 & 0.00 & 73.40 & 0.64 & 0.00 \\
\hline 2 & 13 Apr 2008 & 24.22 & 6 & 45 & 0.01 & 0.01 & 0.00 & 0.00 & 0.57 & 0.00 \\
\hline 12 & 10 Sep 2008 & 23.01 & 2.5 & 90 & 2.72 & 0.19 & 0.01 & 22.60 & 1.88 & 0.01 \\
\hline 14 & 18 Oct 2008 & 20.79 & 5.5 & 30 & 2.71 & 0.17 & 0.01 & 12.76 & 0.38 & 0.08 \\
\hline 4 & 16 May 2008 & 18.77 & 12 & 285 & 4.35 & 0.36 & 0.04 & 82.53 & 2.90 & 0.26 \\
\hline 15 & 24 Oct 2008 & 17.56 & 8 & 180 & 6.36 & 0.71 & 0.03 & 63.71 & 3.32 & 0.08 \\
\hline 11 & 31 Aug 2008 & 16.05 & 4 & 60 & 0.84 & 0.42 & 0.01 & 214.64 & 6.37 & 0.24 \\
\hline 13 & 12 Oct 2008 & 13.93 & 7 & 120 & 1.33 & 0.09 & 0.00 & 22.07 & 0.41 & 0.03 \\
\hline
\end{tabular}

${ }^{1} I_{30}=30 \mathrm{~min}$ maximum rainfall intensity. ${ }^{2}$ Duration of maximum rainfall intensity precipitation. ${ }^{3} \mathrm{Rf}$ : runoff $(\mathrm{mm}),{ }^{4} \mathrm{Sy}:$ sediment yield $\left(\mathrm{g} \mathrm{m}^{-2}\right),{ }^{5} \mathrm{SL}:$ slope.

"coin" and "multcomp" packages of the $\mathrm{R}$ program (R_Development_Core_Team, 2009) using the code of "Tal Galili”, published on r-statistics.com (http://www.r-statistics. com/2010/02/post-hoc-analysis-for-friedmans-test-r-code).

\section{Results}

\subsection{Rainfall characteristics}

A total of 74 rainfall events were registered during the study period, accounting for a total rainfall of $703 \mathrm{~mm}$. During the 2007 hydrological year $550.7 \mathrm{~mm}$ were measured, which was a $18 \%$ above the historical average for the study area $(466.2 \mathrm{~mm})$ reported by Peña et al. (2002). Seventeen events ( $23 \%$ of the total number of events) produced runoff at the slope scale. Characteristics of the runoff-producing rainfall and hydrological responses to these events are shown in Table 3. Average duration and depth of runoff-producing events was $233.8 \mathrm{~min}$ and $36.7 \mathrm{~mm}$ respectively. $I_{30}$ maximum intensity varied from $2.5 \mathrm{~mm} \mathrm{~h}^{-1}$ to $24.8 \mathrm{~mm} \mathrm{~h}^{-1}$.

\subsection{Runoff, erosion and soil moisture at slope and patch scales}

Total runoff and sediment yield decreased from slope 1 to slope 3 in each event (SL1 > SL2 > SL3; Table 3), being this relationship deeper with precipitation events that combined high depth, intensity and duration. At the patch scale, total runoff, runoff coefficients and sediment yield differed significantly between patch types $(p<0.0001$, Friedman test,
Fig. 3). Multiple comparisons between vegetation patches shown in Fig. 3 suggest that there is a gradient of hydrological responses with two extremes: one patch (Genista) showing lower runoff and sediment production and higher soil moisture, and another patch (Medicago) with higher runoff and sediment production rates and lower soil water content. Results combining both scales showed that slope 1 presenting patches with higher runoff and sediment rates (see Table 2 and Fig. 3) also showed higher erosion and runoff rates (Table 3). On the contrary, we found that slope 3 with and important abundance of Genista patches showed the lowest runoff and erosion rates.

\subsection{Hydrological role of vegetation patches vs. rainfall characteristics}

Significant linear relationships between runoff and rainfall depth within each type of patch were obtained. The amount of rain showed a variable effect on runoff depending on type of patch (Fig. 4a). The slope of the regression equation can be used as a parameter to measure the effect of the different vegetation patches on hydrological processes (Fig. 4b). In accordance with runoff yield results, the lowest slope of the regression equation corresponded to the vegetation patch with lowest runoff rates and sediment production (Genista patches), and the highest slope of the regression to the Medicago patches (which had highest runoff and sediment yield rates). 
a)

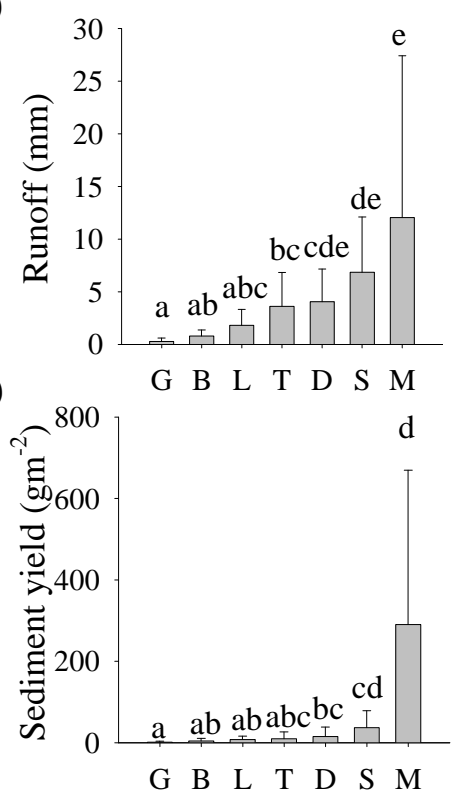

b)

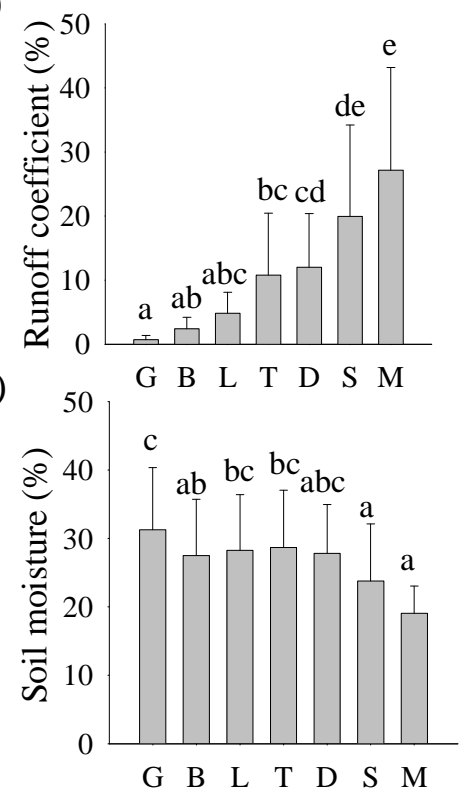

Fig. 3. Hydrological behavior of different vegetation patches. G: Genista; B: Brachypodium; L: Lolium; T: Thymus; D: Dactylis; S: Santolina; M: Medicago. Letters indicate significant differences between groups of patches (post-hoc Wilcoxon-Nemenyi-McDonald-Thompson test, $p<0.05)$.

\subsection{Hydrological groups}

Cluster classification of patch types based on hydrological properties (runoff, runoff coefficient and soil moisture) resulted in 4 groups (Fig. 5). Pooling together with previous results, these four groups were related to four main hydrological roles. One group (runoff sinks) included three types of patches (Genista, Brachypodium, Lolium) with the lowest runoff and sediment production rates and highest soil water content (Fig. 3). It was possible to distinguish two types of sinks within this group; deep sinks $(G)$ and surface sinks $(B$, $L$ ), which appeared slightly different in the cluster classification dendrogram. In contrast with this sink group there were two other groups with higher amount of runoff and sediment yield (Santolina and Medicago), which were assigned as moderate and extreme runoff sources, respectively. A fourth intermediate group was found (low runoff response) which included two types of patches (Dactylis and Thymus) that played the role of poor runoff sources.

Runoff and sediment yield were only recorded for rainfall events that delivered runoff at the foot of slopes (slope-scale runoff producing events). In addition, we used unbounded Gerlach plots to describe the actual hydrological role of these patches; this approach assumes that some high-intensity precipitation events may have connected a greater surface than the estimated catchment areas for each patch. These two design constraints explain the counterintuitive result of classifying a surface patch presenting some (though very low) amounts of runoff and erosion as a runoff sink.

\subsection{Micro-topographic forms}

We found seven micro-topographic forms in the three slopes under study: flat areas, steep flat (flat forms with gradient of $40 \%$ ), concave/convex, preferential sheet-flow, rills, rill fans/splays (where a rill interrupts) and runoff splays (deposition areas formed by water accumulation in micro-terraces built during restoration practices).The preferential sheet-flow areas are small watercourses with more water flow than in places without any geomorphological microstructure (i.e. flat forms). These watercourses could not be considered rills because their depth was very small in comparison with the width. In general, slopes 1 and 2 had a variety of these microtopographic forms while slope 3 was mainly dominated by flat areas (Fig. 6a).

A significant relationship between the hydrological groups and the micro-topographic structures was found on the three slopes $($ Chi-Square $=75.59 ; \mathrm{df}=27 ; p<0.001$, Fig. 6b). On the basis of the differences between observed and expected frequencies, surface sinks were associated with rill fans/splays and microterraces. On the contrary, extreme sources were associated with steep flat micro-topographic forms, and deep sinks $(G)$ were more frequently associated with flat forms.

\subsection{Hydrological heterogeneity at the slope scale}

Runoff coefficient and sediment yield differed significantly between the three slopes $(p<0.0001$, Kruskal-Wallis test, Fig. 7a and b), showing a gradient of soil erosion from 
a)

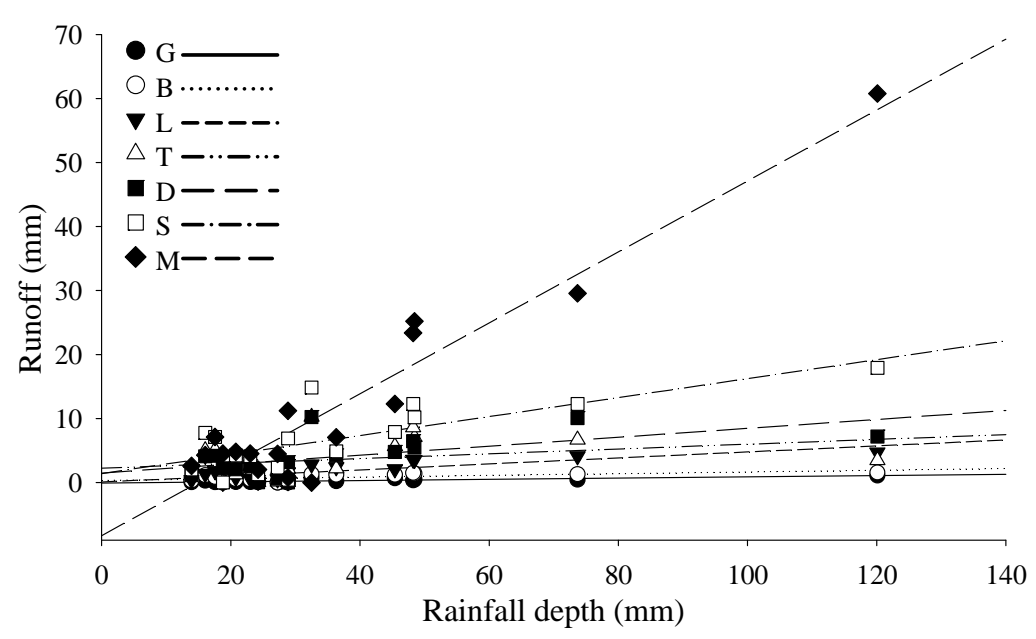

b)

\begin{tabular}{lccc}
\multicolumn{1}{c}{ Vegetation patch } & Equation & p & $\mathbf{r}^{2}$ \\
\hline G. scorpius & Runoff $(\mathrm{mm})$ against Depth $(\mathrm{mm})$ & & \\
B. retusum & $\mathrm{y}=-0.0702+0.0096 * \mathrm{x}$ & 0.00006 & 0.6678 \\
L. perenne & $\mathrm{y}=0.3052+0.0134 * \mathrm{x}$ & 0.00920 & 0.3734 \\
T. vulgaris & $\mathrm{y}=0.0797+0.0469{ }^{*} \mathrm{x}$ & 0.00007 & 0.6621 \\
D. glomerata & $\mathrm{y}=2.2381+0.0374 * \mathrm{x}$ & 0.23000 & 0.0945 \\
S. chamaecyparissus & $\mathrm{y}=1.4735+0.0698^{*} \mathrm{x}$ & 0.01240 & 0.3496 \\
M. sativa & $\mathrm{y}=1.397+0.1483 * \mathrm{x}$ & 0.00060 & 0.5575 \\
& $\mathrm{y}=-8.3062+0.554 * \mathrm{x}$ & 0.00000 & 0.9043
\end{tabular}

Fig. 4. (a) Runoff-rainfall depth relationships obtained for the different patches during the study period (2007-2008). G: Genista; B: Brachypodium; L: Lolium; T: Thymus; D: Dactylis; S: Santolina; M: Medicago. (b) Linear regression equations relating rainfall depth (mm) with runoff $(\mathrm{mm})$ in the different patches.

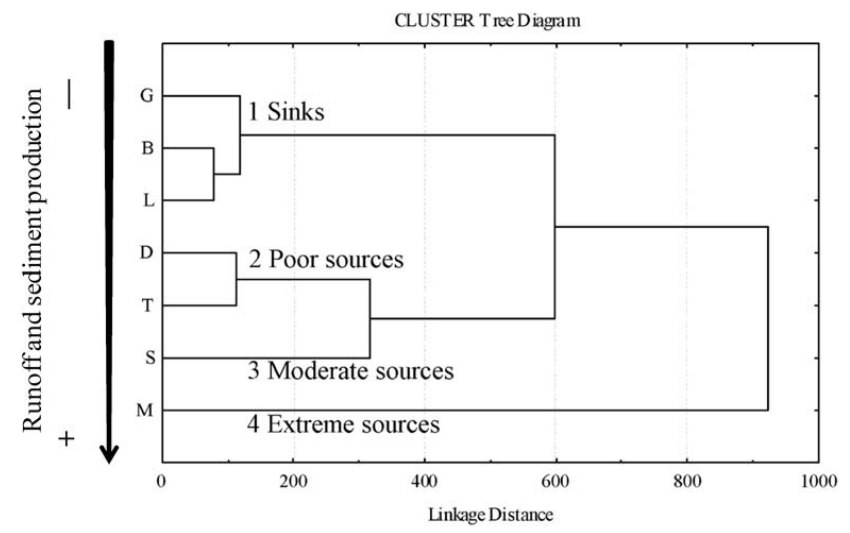

Fig. 5. Dendogram of the cluster classification analysis with hydrological data of the different patches. G: Genista; B: Brachypodium; L: Lolium; T: Thymus; D: Dactylis; S: Santolina; M: Medicago. slope 1 to slope 3. Significant linear relationships were found between runoff and rainfall depth at the slope scale and differences on the slope of those linear relationships suggest a different behaviour for each of the three slopes (Fig. 7c). Slope 1 showed the highest slope of the linear regression, which means that this slope has a strong precipitation-dependent hydrological behaviour. We found the opposite hydrological behaviour (i.e. a weak precipitation dependency) for slope 3 .

Abundance of each of the four hydrological groups of patches obtained from the cluster analysis in the three slopes was compared (Fig. 7d). Extreme sources were found to be absent in slope 3 which was characterized by a fairly homogeneous abundance of sinks, moderate and poor sources. On the contrary, slope 1 was characterized by a dichotomous hydrological role (with extreme and moderate sources and sinks) but without poor source patches, which were most abundant in slope 2. Overall, hydrological diversity increased as overland flow decreased (Fig. 7e). 


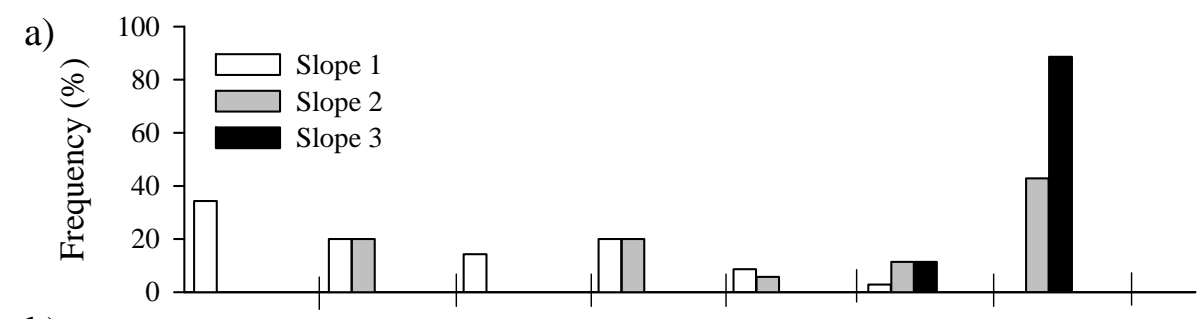

b)

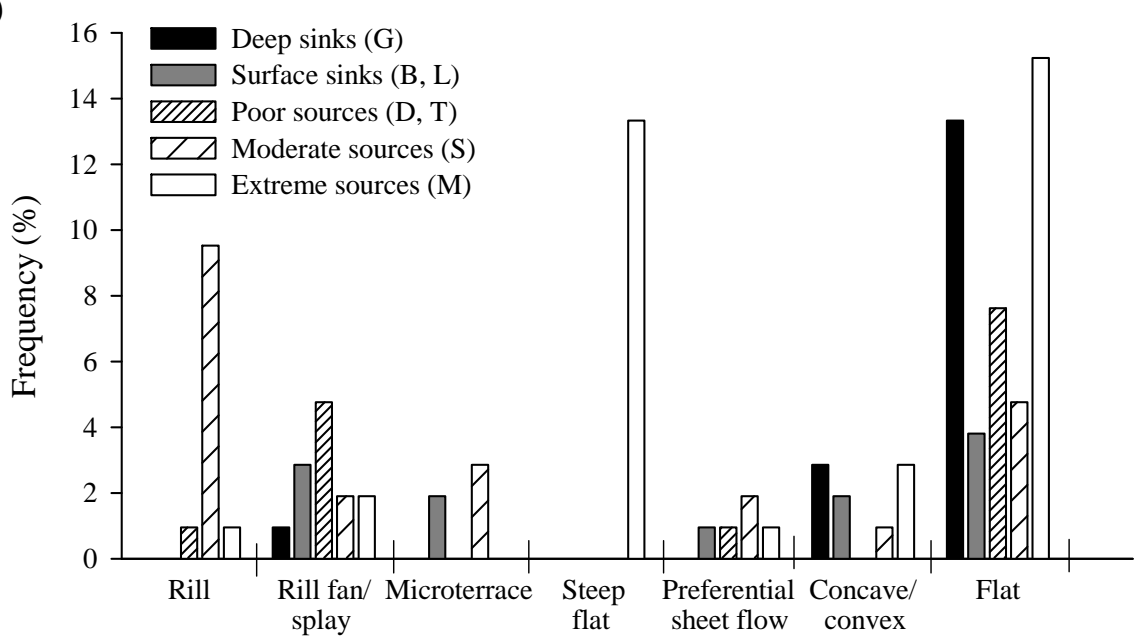

Fig. 6. Micro-topographic structures found on the three slopes under study (a) and relationships to hydrological behavior of vegetation patches (b) $\left(\chi^{2}=86.22 ; \mathrm{df}=34 ; p<0.001\right)$. G: Genista; B: Brachypodium; L: Lolium; T: Thymus; D: Dactylis; S: Santolina; M: Medicago.

\section{Discussion}

\subsection{Patch scale hydrological heterogeneity: ecohydrological role of micro-environments}

Our results showed that patterns of runoff generation, infiltration and routing in reclaimed slopes are highly dependent on the type of patch covering the soil, controlling the final role as a runoff source or sink. The cluster analysis applied to field data of runoff and erosion rates and soil water content in the seven patch types allowed us to identify four "micro-environments" with different hydrological role: (1) sinks (Genista, Brachypodium, Lolium), (2) poor sources (Dactylis, Thymus), (3) moderate sources (Santolina) and (4) extreme sources (Medicago). These findings are supported by comparisons of runoff, sediment yield rates and soil water content, and by the identification of different hydrological responses of patches to rainfall characteristics.

Traditionally, bare patches between plants - characterised by a poor soil structure and a low infiltration capacity - has been described as runoff generating areas. On the contrary, areas under plant clumps function as runoff sinks, where organic matter contents are higher, favouring soil aggregation and soil faunal activity, hence increasing macro-porosity and infiltration rates (Calvo-Cases et al., 2003; Ludwig and Tongway, 1995; Sánchez and Puigdefabregas, 1994). In our study, we have identified the type of plant assemblages that could play both roles (sink/source), as well as the intensity of that role in each case. Thus, our results suggest that the general model developed for semi-arid areas (TTRP) describing two main types of hydrological microenvironments (sources and sinks) should be delved into the case of constructed slopes.

In the studied slopes, sinks were associated with the production of very low amounts of runoff and sediments collected down slope from the patch. Furthermore, these low runoff and sediment yield rates were relatively constant in these patches, even under high precipitation or intense rainfall conditions. These patches are soil surface areas densely covered by grasses (L. perenne, $B$. retusum) or shrubs with a dense herbaceous understory ( $G$. scorpius). B. retusum is a common species following disturbance in Mediterranean environments (Bautista et al., 1996; Cerdà, 1998). It has been described as a good soil protector, with a high erosion control capacity (De Baets et al., 2007) thanks to a dense root system and the consolidation of soil aggregates (Cerdà, 1998). $B$. retusum patches showed low runoff and erosion rates and also, low amounts of soil water content at $25 \mathrm{~cm}$ after rainfall, which could suggest that this species is highly effective for obstructing runoff and sediments although it is not so effective for deep water infiltration (e.g. through macropore flow). In fact, results and field observations showed $B$. retusum clumps splaying rather than retaining the water and sediment flow. These findings are consistent with those obtained by Arnau Rosalén et al. (2008) who found that the 


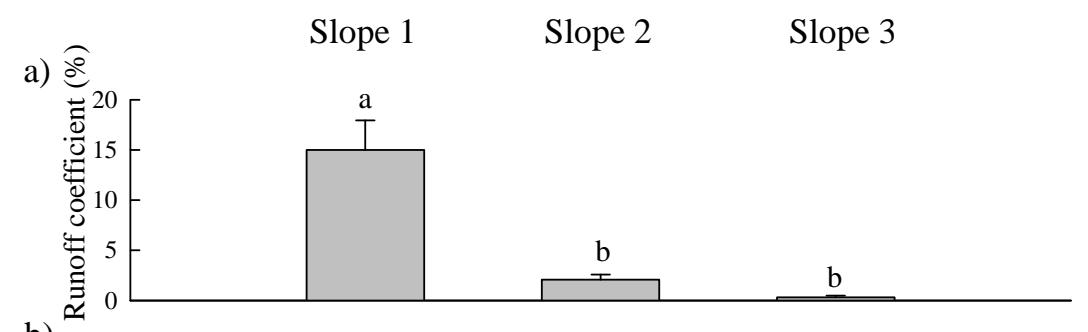

b)

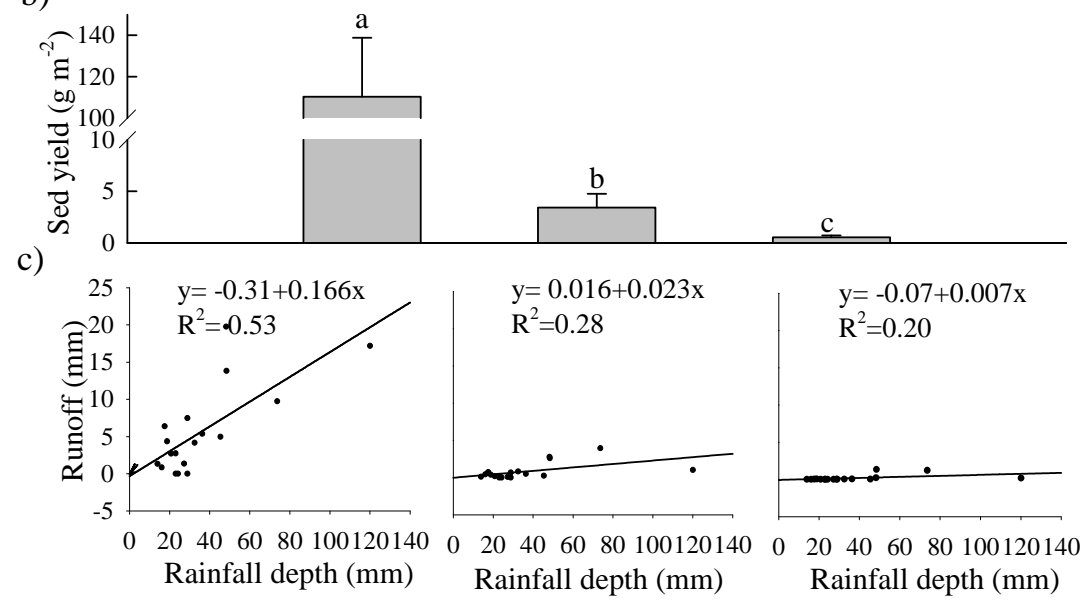

d)
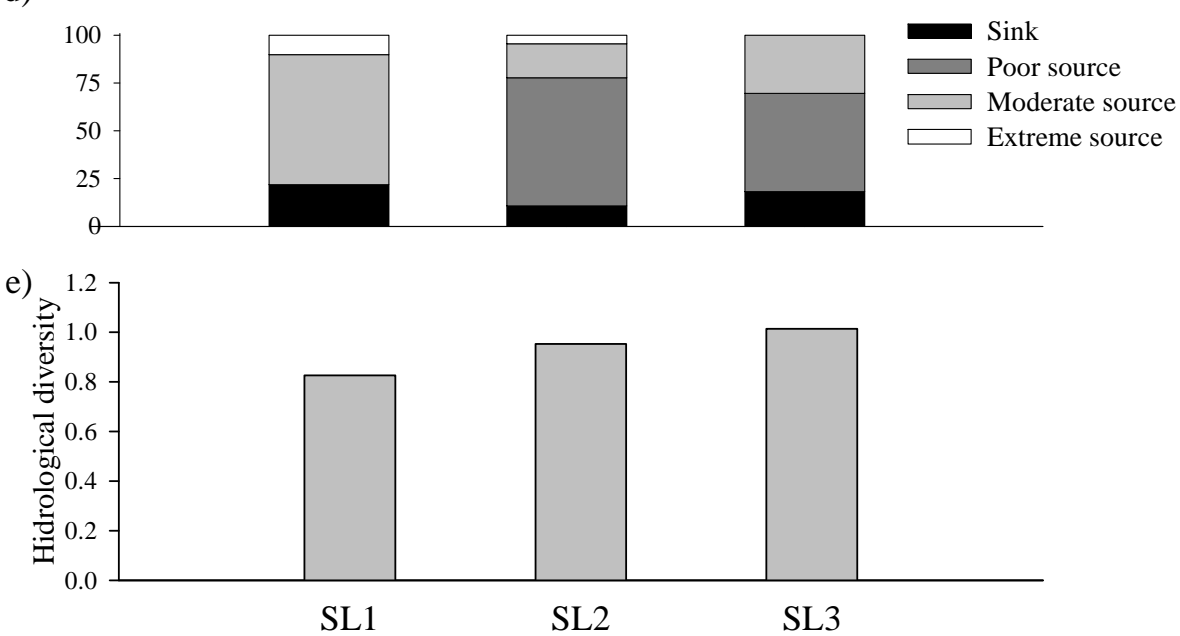

Fig. 7. Slope hydrology and hydrological heterogeneity. (a) Runoff coefficient (\%), (b) sediment yield ( $\mathrm{g} \mathrm{m}^{-2}$ ), (c) runoff-rainfall depth relationship, (d) hydrological group abundance, (e) hydrological diversity.

B. retusum patches have a high infiltration capacity but reach runoff stability (i.e. steady runoff) very quickly. Mayor et al. (2009) also obtained similar findings with rainfall simulations under this vegetation patch. Ryegrass (L. perenne) is not a characteristic species of Mediterranean degraded environments; it was introduced during revegetation practices. The effects of ryegrass in reducing runoff and erosion rates have been broadly described (Zhou and Shangguan, 2007). It has been found that canopies of ryegrass usually contribute to runoff declines to a greater extent than roots, whereas roots contributed mainly to a strong decrease in sediment yields
(Zhou and Shangguan, 2008). We also found that this patch was highly effective for obstructing runoff and sediments, although it is the sink with the highest runoff and erosion rates and the most precipitation-dependent hydrological behaviour. Genista patches had the lowest runoff and erosion rates and the highest soil water content. Higher soil moisture content after rainfall (which is a good indicator of a runoff sink role) suggests that this patch is not only effective for obstructing runoff and sediments; it also enhances deep (macropore) infiltration that in turn increases soil moisture. In fact, we found that the soil characteristics of G. scorpius 
understorey are significantly different, with lower bulk density and surface strength than the other patches. The deeply infiltrated water is easily conserved against evaporation and can be used by G. scorpius and associated plants during dry periods. Molinillo et al. (1997) found also that under a dense G. scorpius cover, both runoff and sediment yield are strongly controlled.

Briefly, our results emphasize the presence of a variety of sink roles dependent on plant community characteristics; G. scorpius patch could be considered as a "deep sink", while B. retusum and L. perenne could be described as "surface sinks" or "runoff splays".

Previous studies found that micro-topography has a net effect on runoff and sediments redistribution in slopes and catchments (Mayor et al., 2008). Similarly, our results suggest an interrelation between the organization of patch-scale sink roles and micro-topographic structures. The three selected slopes represent a gradient of overland flow from discontinuous rilling to very low amounts of runoff routing as sheet flow along the slopes. This gradient generated different micro-topographies through soil erosion: rills and rill-fans in the slope with highest runoff volumes (slope 1), splays when runoff volumes decreased (slope 2), and absence of microtopographic structures in the slope with low runoff volumes (slope 3). These results are supported by the fact that two of the three types of sink patches described (Lolium and Brachypodium) are related to microterraces and splays forms (field observations related Lolium to rill fans and Brachypodium to splays). Thus, we suggest that the proliferation of these patch types was related, in the early stages of succession, to the existence of these micro-structures. In fact, the characteristic species $L$. perenne is a residual species from initial revegetation practices subsisting under favourable conditions generated by rill fans. On the other hand, B. retusum, which is a pioneer species typical of degraded environments, would have colonized only the splays where it can persist. These findings are in accordance with Wainwright et al. (2002), who worked in areas with discontinuous flow pattern with alternating areas of channelization and deposition. They found that rill fans (they called these areas "beads") were the areas with higher concentrations of nutrient, water and seed resources, describing these sites as "islands of fertility" (sensu Garner and Steinberger, 1989) that facilitate the establishment and growth of vegetation. A different situation is found in slope 3, where different runoff volumes have not eroded the surface differently and have not generated different micro-structures. Therefore, we suggest that the colonization of Genista in this slope is independent of the generation of favourable hydric microenvironments and that their initial spatial distribution was conditioned by other abiotic and biotic factors.

Overall, we can say that the origin and spatial organization of the observed patches with sink behaviour responds to the two distinctive mosaic-generating processes mentioned by Puigdefábregas et al. (1999): mosaics driven by differential erosion, where plant cover plays a passive role (slopes 1 and 2), and mosaics resulting from "nucleation" processes (slope 3), where vegetated patches become hot-spots of soil and vegetation change. The gradient of overland flow routing along the slope influences these mosaic generation processes, shifting the driving force of mosaic generation towards an abiotic control under higher overland flow volumes. Other authors (Boix-Fayos et al., 2005; Lavee et al., 1998) found similar results for aridity gradients, finding that the biological control of soil erosive processes becomes more important when aridity decreases. In this research, we found that these results can also be obtained for gradients in overland flow running through the slopes.

In contrast with the sink roles described, Medicago and Santolina patches played an obvious role as sources. Medicago patches had the highest runoff rates and sediment yield (considered extreme sources of runoff), followed by Santolina (moderate runoff source). Medicago patches showed also a scarce controlling effect on hydrological processes in comparison with other patches, which could be due to their high proportion of bare soil (vegetation cover is less than $3 \%$ in Medicago patches). Similar runoff and erosion rates were obtained in bare soil by other authors (Cerdà, 1997). Santolina patches are patches of scattered dwarf-shrubs with a vegetation cover of around $20 \%$, which is rather high for the runoff and erosion rates that were measured.

Within these contrasting hydrological roles we found two patches (Thymus and Dactilys) which belong to vegetated inter-patches areas with cover ranging from 15 to $25 \%$. These areas are covered by scattered dwarf shrubs (T. vulgaris) or tussocks of orchardgrass (D. glomerata). Both species are characteristic of semi-natural Mediterranean environments. T. vulgaris develops on relatively erodible soils (Cerdà, 1998), whereas the growth of $D$. glomerata has been described as good for erosion control, although not as good as L. perenne (Gokbulak, 2003). However, they play a similar hydrological role which could be explained by differences in cover $(23.33 \%$ for T. vulgaris and $17.33 \%$ for D. glomerata).

Our results confirm that not only plant cover plays a main role for hydrological control in inter-patch areas, but plant morphology is also important. Although Santolina patches had a similar vegetation cover to those of Thymus or Dactylis, they have significantly higher erosion rates. This result agrees with those of Bochet et al. (2006), who found that rates of soil loss and runoff reduction varied strongly between three different Mediterranean species because of different plant morphology and features.

\subsection{Slope scale hydrological heterogeneity: effects of overland flow}

Our experimental design, which included three slopes subjected to the influence of a range of upslope runoff generation, allowed us to evaluate the effect of overland flow on 
hydrological heterogeneity. The particular influence of runon (in this case runoff contributions from upslope structures) on the ecohydrology of these constructed systems must be taken into account. Moreno-de las Heras et al. (2009) reported a trend towards hydrological and ecological simplification when run-on causes the development of dense rill networks. Our results, referred to as non-concentrated overland flow regimes, illustrate how when the amount of overland flow routing along slopes decreases, hydrological heterogeneity increases. We obtained the highest runoff and erosion rates for slope 1 , which developed some discontinuous rills, finding significant differences with the other two nonrilled slopes. Moreover, we obtained very different rainfallrunoff relationships for the set of experimental slopes, with slope 1 being highly dependent on rainfall volume, which together with the previous result, suggests a greater spatial connectivity of runoff and sediments in this slope compared with slopes 2 and 3 . In fact, these results can be explained as a consequence of the development of discontinuous rills, which increase runoff connectivity and consequently, runoff and soil erosion rates (Nicolau, 2002; Bracken and Croke, 2007; Bracken and Kirkby, 2005).

The proportion of runoff sources decreased along the overland flow gradient represented by the slopes. The extreme sources are absent in slope 3 where we found the lowest runoff coefficient. Moreover, this slope presented the highest values of "hydrological diversity" (an index influenced by both the richness and proportion of each hydrological group). This slope hosts conditions for the development of a very efficient sink, clumps of $G$. scorpius with a dense understorey of grasses and forbs. This sink shows a remarkable capacity for overland flow interception as well as for increasing soil water content at $25 \mathrm{~cm}$ depth. These properties facilitate the development of vegetation and the spread of plant cover, leading the reclaimed ecosystem towards more complex states. Thus, we can say that as upslope generation of overland flow becomes less important in theses slopes, hydrological heterogeneity increases and is driven by vegetation, promoting a variety of sinks and low runoff production areas. Moreover, hydrological connectivity (i.e. the continuity of runoff and the flow of sediments through the slopes) decreases and water availability for plants increases, reinforcing the trend towards the biological control of the hydrological processes.

Our experimental design also allows us to discuss these results under the perspective of the evolution of sink-source patterns as ecological succession (highly influenced by overland flow volumes) proceeds in these reclaimed ecosystems. This phenomenon has been scarcely analysed: most previous studies depict hydrological heterogeneity for stable systems throughout the world where sources and sinks are coupled under a dynamic equilibrium state (Ludwig et al., 1997, 2005), or address the stability of coupled systems under several types of disturbances, mainly fires and overgrazing, which reduce vegetation cover, and thus runoff obstruction, increasing runoff and erosion rates (Wilcox et al., 2003; McIvor et al., 1995; Scanlan et al., 1996). Our research describes the variation of the sink-source pattern in a gradient of ecological recovery (driven by a gradient of overland flow volume) after slope reclamation. Thus, when upslope runoff generation decreases and the vegetation is able to reach a higher level of complexity, a new type of sink develops: the Genista scorpius deep sink, with a dense plant understorey. These sink patches significantly increase the biological control of hydrological processes in reclaimed slopes.

\subsection{Applied ecohydrological concepts for the design of reclaimed slopes}

We found that the TTRP framework proposed by Ludwig et al. $(1997,2005)$ could be useful for the further understanding of the long-term evolution of these human-made environments. In addition, our results showed that overland flow is a driving factor for sink-source patterns development and therefore, for ecological succession of restored slopes under Mediterranean climate. As a result, this component should not be missed when considering the topographic design of restored slopes.

We have found a deep-sink patch dominated by the shrub species Genista scorpius that enhanced the biological control of hydrological processes, notably increasing the soil moisture availability for plant production. More research is needed to investigate whether the water accumulated in this patch type facilitates the expansion of vegetation in the slopes. This is particularly important for restoration purposes of these human-made systems, since vegetation is particularly scarce during their early stages of succession (typically ranging $20-40 \%$ ) and their long-term stability largely depends on the establishment of optimal levels of vegetation cover (Moreno-de las Heras et al., 2011; Bochet et al., 2010). Thus, the introduction of vegetation patches with keystone species such as Genista scorpius during slope revegetation practices could help to accelerate the recovery of similar severely disturbed Mediterranean landscapes.

\section{Conclusions}

Runoff generation and routing in constructed slopes that have not developed continuous rill networks revealed a pattern of source and sink areas. Such hydrological microenvironments were associated to seven patches (characterized by different plant communities and cover). Two types of sink patches were identified: $G$. scorpius community, considered as a "deep sink"; B. retusum and L. perenne described as "surface sinks". Surface sinks were related to previous microstructures while the deep sinks were not related to a previous microtopography. A range of sources were also identified, spanning from "extreme sources" of $M$. sativa (equivalent to bare soil) to "poor sources": areas with scattered dwarf 
shrubs (Thymus vulgaris) or herbaceous orchardgrass tussocks (Dactylis glomerata).

The hydrological diversity was related to volume of overland flow routing along the slope. As overland flow at slope scale increases, hydrological diversity decreases and it is driven by overland flow, developing contrasted hydrological roles (extreme sources and sinks). In fact, when runoff generation in the upper part of the slope stops, the tempered roles (poor sources) become more abundant and a qualitative change occurs as the deep sink formed by patches of G. scorpius emerges, hydrological diversity being driven by vegetation in this case. This trend towards an increase in hydrological diversity and the development of deep sinks reflects the evolution through time of the constructed slopes when ecological succession is not "arrested" by overland flow. Thus, in this case, the described pattern of runoff sinks and sources is probably not stable in the long term, but could evolve towards a greater biological control of hydrological processes through the expansion of vegetation.

Acknowledgements. This work was supported by the Universidad de Alcalá, the project CGL2010-21754-C02-02 from Ministerio de Ciencia e Innovación of the Spanish government and the project REMEDINAL (S2009AMB-1783), funded by the Regional Government of Madrid. We are grateful to the Utrillas Council for their active collaboration. We are also grateful to Oscar Godoy and Sara Godoy for their fieldwork help and Lucia Gálvez and Patricia Tabernero for language editing and Mariola Merino Martín for her help editing the figures. We are very grateful to José Antonio Merino Martín for his fieldwork help and his help with the spatial data. We are very grateful for the comments given by C. Boix-Fayos, L. Bracken and an anonymous referee that helped us to improve the final manuscript.

Edited by: E. Morin

\section{References}

Arnau-Rosalen, E., Calvo-Cases, A., Boix-Fayos, C., Lavee, H., and Sarah, P.: Analysis of soil surface component patterns affecting runoff generation. An example of methods applied to mediterranean hillslopes in alicante (Spain), Geomorphology, 101, 595-606, doi:10.1016/j.geomorph.2008.03.001, 2008.

Bautista, S., Bellot, J., and Vallejo, V. R.: Mulching treatment for postfire soil conservation in a semiarid ecosystem, Arid Soil Res. Rehab., 10, 235-242, 1996.

Bochet, E., Poesen, J., and Rubio, J. L.: Runoff and soil loss under individual plants of a semi-arid mediterranean shrubland: Influence of plant morphology and rainfall intensity, Earth Surf. Proc. Land., 31, 536-549, 2006.

Bochet, E., Garcia-Fayos, P., and Tormo, J.: How can we control erosion of roadslopes in semiarid Mediterranean areas? Soil improvement and native plant establishment, Land Degrad. Dev., 21, 110-121, doi:10.1002/ldr.911, 2010.
Boix-Fayos, C., Martinez-Mena, M., Calvo-Cases, A., Castillo, V., and Albaladejo, J.: Concise review of interrill erosion studies in SE Spain (alicante and murcia): Erosion rates and progress of knowledge from the 1980s, Land Degrad. Dev., 16, 517-528, 2005.

Boix-Fayos, C., Martinez-Mena, M., Arnau-Rosalen, E., CalvoCases, A., Castillo, V., and Albaladejo, J.: Measuring soil erosion by field plots: Understanding the sources of variation, EarthSci. Rev., 78, 267-285, doi:10.1016/j.earscirev.2006.05.005, 2006.

Bracken, L. J. and Croke, J.: The concept of hydrological connectivity and its contribution to understanding runoff-dominated geomorphic systems, Hydrol. Process., 21, 1749-1763, 2007.

Bracken, L. J. and Kirkby, M. J.: Differences in hillslope runoff and sediment transport rates within two semi-arid catchments in southeast Spain, Geomorphology, 68, 183-200, doi:10.1016/j.geomorph.2004.11.013, 2005.

Bradshaw, A. D.: The reconstruction of ecosystems: Presidential address to the british ecological society, December 1982, J. Appl. Ecol., 20, 1-17, 1983.

Bromley, J., Brouwer, J., Barker, A. P., Gaze, S. R., and Valentine, C.: The role of surface water redistribution in an area of patterned vegetation in a semi-arid environment, south-west Niger, J. Hydrol., 198, 1-29, 1997.

Calvo-Cases, A., Boix-Fayos, C., and Imeson, A. C.: Runoff generation, sediment movement and soil water behaviour on calcareous (limestone) slopes of some mediterranean environments in southeast Spain, Geomorphology, 50, 269-291, 2003.

Cammeraat, L. H.: A review of two strongly contrasting geomorphological systems within the context of scale, Earth Surf. Proc. Land., 27, 1201-1222, doi:10.1002/esp.421, 2002.

Cassel, D. K., Kachanoski, R. G., and Topp, G. C.: Practical considerations for using a tdr cable tester, Soil Technol., 7, 113-126, 1994.

Cerdà, A.: The effect of patchy distribution of stipa tenacissima $\mathrm{L}$ on runoff and erosion, J. Arid Environ., 36, 37-51, 1997.

Cerdà, A.: Soil aggregate stability under different Mediterranean vegetation types, Catena, 32, 73-86, 1998.

Davenport, D. W., Breshears, D. D., Wilcox, B. P., and Allen, C. D.: Viewpoint: Sustainability of pinon-juniper ecosystems - a unifying perspective of soil erosion thresholds, J. Range Manage., 51, 231-240, 1998.

De Baets, S., Poesen, J., Knapen, A., Barbera, G. G., and Navarro, J. A.: Root characteristics of representative mediterranean plant species and their erosion-reducing potential during concentrated runoff, Plant Soil, 294, 169-183, 2007.

Dunkerley, D. L. and Brown, K. J.: Runoff and runon areas in a patterned chenopod shrubland, arid western New-South-Wales, Australia - characteristics and origin, J. Arid. Environ., 30, 41$55,1995$.

Espigares, T., Moreno-de las Heras, M., and Nicolau, J. M.: Performance of vegetation in reclaimed slopes affected by soil erosion, Restor. Ecol., 19, 35-44, 2011.

Garcia-Estringana, P., Alonso-Blazquez, N., Marques, M. J., Bienes, R., and Alegre, J.: Direct and indirect effects of mediterranean vegetation on runoff and soil loss, Eur. J. Soil Sci., 61, 174-185, doi:10.1111/j.1365-2389.2009.01221.x, 2010. 
Garner, W. and Steinberger, Y.: A proposed mechanism for the formation of fertile islands in the desert ecosystem, J. Arid Environ., 16, 257-262, 1989.

Gokbulak, F.: Comparison of growth performance of lolium perenne $\mathrm{L}$., dactylis glomerata $\mathrm{L}$. and agropyron elongatum (host.) P. Beauv., For erosion control in Turkey, J. Environ. Biol., 24, 45-53, 2003.

Hancock, G. R. and Willgoose, G. R.: An experimental and computer simulation study of erosion on a mine tailings dam wall, Earth Surf. Proc. Land., 29, 457-475, doi:10.1002/esp.1045, 2004.

Hollander, M. and Wolfe, D. A.: Nonparametric statistical methods, 2nd Edn., John Wiley \& Sons, Inc, New York, 1999.

Lavee, H., Imeson, A. C., and Sarah, P.: The impact of climate change on geomorphology and desertification along a mediterranean-arid transect, Land Degrad. Dev., 9, 407-422, 1998.

Ludwig, J. A. and Tongway, D. J.: Spatial-organization of landscapes and its function in semiarid woodlands, Australia, Landscape Ecol., 10, 51-63, 1995.

Ludwig, J. and Tongway, D.: Viewing rangelands as landscape systems, in: Rangeland desertification, edited by: Arnalds, O. and Archer, S., Advances in vegetation science, Kluwer Academic, Dordrecht, The Netherlands, 39-52, 2000.

Ludwig, J., Tongway, D., Freudenberger, D., Noble, J., and Hodgkinson, K.: Landscape ecology, function and management: Principles from australia's rangelands, CSIRO Publishing, Melbourne, Australia, 1997.

Ludwig, J. A., Wilcox, B. P., Breshears, D. D., Tongway, D. J., and Imeson, A. C.: Vegetation patches and runoff-erosion as interacting ecohydrological processes in semiarid landscapes, Ecology, 86, 288-297, 2005.

MAPA: Métodos oficiales de análisis, in: Tomo iii. Secretaría general de alimentación, Dirección general de política alimentária, Ministerio de agricultura, pesca y alimentación, Madrid, Spain, 1994.

Mayor, A. G., Bautista, S., Small, E. E., Dixon, M., and Bellot, J.: Measurement of the connectivity of runoff source areas as determined by vegetation pattern and topography: A tool for assessing potential water and soil losses in drylands, Water Resour. Res., 44, W10423, doi:10.1029/2007wr006367, 2008.

Mayor, Á. G., Bautista, S., and Bellot, J.: Factors and interactions controlling infiltration, runoff, and soil loss at the microscale in a patchy Mediterranean semiarid landscape, Earth Surf. Proc. Land., 34, 1702-1711, 2009.

McIvor, J. G., Williams, J., and Gardener, C. J.: Pasture management influences runoff and soil movement in the semiarid tropics, Aust. J. Exp. Agr., 35, 55-65, 1995.

Merino-Martín, L., Breshears, D. D., Moreno-de las Heras, M., Villegas, J. C., Pérez-Domingo, S., Espigares, T., and Nicolau, J. M.: Ecohydrological interrelationships between vegetation patches and soil hydrological properties along a disturbance gradient: How sources and sinks of runoff determine a restoration threshold, Restor. Ecol., 20, 360-368, doi:10.1111/j.1526100X.2011.00776.x, 2011.

Molinillo, M., Lasanta, T., and GarciaRuiz, J. M.: Managing mountainous degraded landscapes after farmland abandonment in the Central Spanish Pyrenees, Environ. Manage., 21, 587-598, 1997.
Moreno-de las Heras, M., Nicolau, J. M., and Espigares, T.: Vegetation succession in reclaimed coal-mining slopes in a Mediterranean-dry environment, Ecol. Eng., 34, 168-178, 2008.

Moreno-de las Heras, M., Merino-Martín, L., and Nicolau, J. M.: Effect of vegetation cover on the hydrology of reclaimed mining soils under Mediterranean-continental climate, Catena, 77, 3947, 2009.

Moreno-de las Heras, M., Nicolau, J. M., Merino-Martin, L., and Wilcox, B. P.: Plot-scale effects on runoff and erosion along a slope degradation gradient, Water Resour. Res., 46, W04503, doi:10.1029/2009wr007875, 2010.

Moreno-de las Heras, M., Espigares, T., Merino-Martín, L., and Nicolau, J. M.: Water-related ecological impacts of rill erosion processes in Mediterranean-dry reclaimed slopes, Catena, 84, 114-124, 2011.

Morgan, R. P. C.: Factors influencing erosion, in: Soil Erosion and Conservation, edited by: Morgan, R. P. C., Longman, Essex, UK, 26-39, 1995.

Nicolau, J. M.: Runoff generation and routing on artificial slopes in a Mediterranean-continental environment: The teruel coalfield, Spain, Hydrol. Process., 16, 631-647, 2002.

Nicolau, J. M.: Trends in relief design and construction in opencast mining reclamation, Land Degrad. Dev., 14, 215-226, 2003.

Noy-Meir, I.: Desert ecosystems: Environment and producers, Ann. Rev. Ecol. System., 4, 25-51, 1973.

Papadakis, J.: Climates of the world and their agricultural potentialities, edited by: Papadakis, J., Buenos Aires, 1966.

Peña, J. L., Cuadrat, J. M., and Sanchez, M.: El clima de la provincia de teruel, in: Cartilla turolense, Instituto de Estudios Turolenses (CSIC), Teruel, 2002.

Puigdefábregas, J., Sole, A., Gutierrez, L., del Barrio, G., and Boer, M.: Scales and processes of water and sediment redistribution in drylands: Results from the Rambla Honda field site in southeast Spain, Earth-Sci. Rev., 48, 39-70, 1999.

Puigdefábregas, J.: The role of vegetation patterns in structuring runoff and sediment fluxes in drylands, Earth Surf. Proc. Land., 30, 133-147, 2005.

R_Development_Core_Team: R: A language and environment for statistical computing, in: R Foundation for Statistical Computing, Vienna, Austria, 2009.

Reid, K. D., Wilcox, B. P., Breshears, D. D., and MacDonald, L.: Runoff and erosion in a Pinon-Juniper woodland: Influence of vegetation patches, Soil Sci. Soc. Am. J., 63, 1869-1879, 1999.

Richards, L. A.: A pressure-membrane extraction apparatus for soil solution, Soil Sci., 51, 377-386, doi:10.1097/00010694194105000-00005, 1941.

Sánchez, G. and Puigdefabregas, J.: Interactions of plant-growth and sediment movement on slopes in a semiarid environment, Geomorphology, 9, 243-260, 1994.

Scanlan, J., Pressland, A., and Myles, D.: Run-off and soil movement on mid-slopes in north-east Queensland [Australia] grazed woodlands, Rangeland J., 18, 33-46, doi:10.1071/RJ9960033, 1996.

Schlesinger, W. H., Reynolds, J. F., Cunningham, G. L., Huenneke, L. F., Jarrell, W. M., Virginia, R. A., and Whitford, W. G.: Biological feedbacks in global desertification, Science, 247, 10431048, 1990. 
Seghieri, J., Galle, S., Rajot, J. L., and Ehrmann, M.: Relationships between soil moisture and growth of herbaceous plants in a natural vegetation mosaic in niger, J. Arid Environ., 36, 87-102, 1997.

Statsoft: Statistica, in: Data analysis software system, Tulsa, OK, 2001.

Tryon, R. C.: Cluster analysis, Edwards Brothers, Ann Arbor, Michigan, 1939.

Turnbull, L., Wainwright, J., and Brazier, R. E.: A conceptual framework for understanding semi-arid land degradation: Ecohydrological interactions across multiple-space and time scales, Ecohydrology, 1, 23-34, doi:10.1002/eco.4, 2008.

Turnbull, L., Wainwright, J., Brazier, R. E., and Bol, R.: Biotic and abiotic changes in ecosystem structure over a shrubencroachment gradient in the southwestern USA, Ecosystems, 13, 1239-1255, doi:10.1007/s10021-010-9384-8, 2010.

Vasquez-Mendez, R., Ventura-Ramos, E., Oleschko, K., Hernandez-Sandoval, L., Parrot, J. F., and Nearing, M. A.: Soil erosion and runoff in different vegetation patches from semiarid Central Mexico, Catena, 80, 162-169, doi:10.1016/j.catena.2009.11.003, 2010.
Wainwright, J., Parsons, A. J., Schlesinger, W. H., and Abrahams, A. D.: Hydrology-vegetation interactions in areas of discontinuous flow on a semi-arid Bajada, Southern New Mexico, J. Arid Environ, 51, 319-338, 2002.

White, L. P.: Vegetation arcs in Jordan, J. Ecol., 57, 461-464, 1969.

Wilcox, B. P., Breshears, D. D., and Allen, C. D.: Ecohydrology of a resource-conserving semiarid woodland: Effects of scale and disturbance, Ecol. Monogr., 73, 223-239, 2003.

Zhou, Z. C. and Shangguan, Z. P.: The effects of ryegrass roots and shoots on loess erosion under simulated rainfall, Catena, 70, 350-355, doi:10.1016/j.catena.2006.11.002, 2007.

Zhou, Z. C. and Shangguan, Z. P.: Effect of ryegrasses on soil runoff and sediment control, Pedosphere, 18, 131-136, 2008. 